\title{
LEI NATURAL X CONVENÇÃO DOS ANTIGOS
}

\author{
SELVINO ANTONNIO MALFATTI
}

MALFATTI, S.A. Lei natural x convenção dos antigos. Semina: Londrina, Ci. Sociais/Humanas, v. 17 ,
n. 3, p. 321-329, set. 1996.

RESUMO: O presente artigo traz o debate entre os gregos antigos sobre a natureza da lei. Basicamente duas correntes defrontaram-se: os defensores da lei natural e os convencionalistas. Entre os primeiros podem ser citados Sócrates, Platão, Aristóteles e os estóicos. Nos segundos encontram-se os sofistas e os epicureus. Os partidários da idéia de lei natural argumentavam que o homem nascia com uma lei e que ao cumpri-la se estaria fazendo justiça. Em torno desta idéia se poderia obter o consenso da sociedade sobre o que fazer e o que não fazer. O consenso dar-se-ia em questões fundamentais e com isso a lei poderia ser duradoura, geral, acima dos interesses dos grupos, e principalmente justa. Os convencionalistas, ao contrário, pensavam que o dito consenso era só disfarce do grupo hegemônico. E se a lei fosse um mero capricho do grupo dominante, ela seria efêmera, particular, casuísta, e principalmente uma força impositiva. Este debate foi tão significativo que não se extraviou na História mas suportou a Idade Média e reacendeu na Idade Moderna com o contratualismo, subdividido entre jusnaturalistas partidários de uma lei natural e convencionalistas, defensores da relatividade absoluta das leis. Até mesmo na Idade Contemporânea se defrontaram e se defrontam as duas vertentes, evidentemente revestidas com outras roupagens. Boa parte dos liberais, por exemplo, são caudatários do jusnaturalismo e boa parte dos marxistas seguem a linha convencionalista. Com certeza, atualmente os defensores do "direito alternativo" deitam suas raízes no convencionalismo, e os alinhados na idéia de um direito impessoal devem sua inspiração ao direito natural.

PALAVRAS-CHAVE: Lei natural, convenção, consenso e relativismo jurídico.

\section{INTRODUÇÃO}

Na idade Moderna tornou-se hegemônica uma idéia-eixo que imantou em torno de si pensadores políticos de diversas tendências ideológicas. Trata-se do contratualismo, que concretamente propugnava para a queda do absolutismo, divisão e limitação do poder e instituição de um governo de origem popular. 0 contratualismo, porém, não somente dizia respeito a questões de governo - relações entre governantes e governados - mas também à consociação dos cidadãos, na participação dos bens, submetidos às mesmas leis.

Precisamente na concepção de lei é que se estabelece uma das mais radicais clivagens entre os contratualistas. Neste particular, a divisão que se poderia estabelecer era entre os partidários do jusnaturalismo e os partidários do convencionalismo. Entre os primeiros podem ser alocados Jean Bodin, Hugo Grócio, Thomas Hobbes, Samuel Pufendorf, culminando com John Locke. Entre os segundos poderiam ser enumerados François-Vicent Toussaint, Claude-Adrien Helvetius, François-Marie Arouet, Denis Diderot, Paul Henri Dietrich, culminando com Jean-Jacques Rousseau.
Dentre os primeiros tomamos como protótipo Locke, e entre os segundos Rousseau.

Os jusnaturalistas defendem um direito natural (evidentemente além do positivo) e the atribuem procedência e supremacia em relação aos demais direitos e leis. Associam-lhe também uma lei natural ou uma lei da natureza pela qual o homem se toma partícipe do cosmos e mesmo da divindade. Os direitos naturais não podem ser objeto de questionamento por parte do poder político, pela maioria, minoria ou por qualquer que seja. Eles, a priori, devem ser reconhecidos. As leis naturais - contextualizadas no direito natural - devem ser a priori e de imediato acatadas como normas a nortear as leis positivas. Nesse aspecto a natureza seria ao mesmo tempo um modelo e uma fonte inesgotável de pesquisa por parte do homem. Năo, porém, qualquer natureza, mas a humana. Por isso a lei natural é a lei presente no homem, que chega mesmo a ser atribuída à divindade, embora Grocio evite deixá-la na dependência de Deus. Mesmo em autores autoritários, como Hobbes, a transferência de todas as prerrogativas ao Leviathan faz-se para garantir os direitos primeiros e a lei natural, diz seu autor. Os convencionalistas são

* Professor Titular aposentado da UFSM.

Semina Ci. Sociasis/Hum., v. 17, n, 3, p. 321-329 
contra a existência de um direito natural e interpretam diferente a lei natural. Conforme Rousseau, esta não pode ser buscada na experiência, na história ou em qualquer que seja a sociedade constituída. Nesses casos ela já está deturpada. O único método para se chegar a ela é através da razão. Guiados por ela chegamos a um tipo de homem individual, puro, sem ciência nem arte, dotado de um sentimento geral de "humanidade". E como esse homem não existe mais e nem poderá existir, pois está corrompido pela ciência e técnica, devem-se elaborar outras leis, aquelas que a razão dos homens convencionarem que serão as melhores. As leis, portanto, não tem outro fundamento que não a convenção.

O contratualismo jusnaturalista de Locke deu origem ao liberalismo, doutrina esta, que reconhecia no indivíduo direitos originários e inalienáveis. Em relação ao poder político-social, considerava tanto a sociedade como o Estado, uma obra humana, não decorrente de leis naturais, mas de um acordo entre os individuos, embora sua origem última possa ter-se inspirado no modelo de família.

O contratualismo convencionalista de Rousseau deu origem ao democratismo, conforme afirma François Furet ${ }^{\dagger}$. A sociedade e o Estado também foram considerados obras da reflexão humana, no sentido de soltar os ferros a que os homens estavam algemados pelo sistema político vigente. A nova ordem a ser erigida devia abandonar a tradição, as leis constituídas, a divisão social e organizar algo racional sobre aquilo que homens racionais convencionarem acordar. Direitos naturais não existiriam. Esta distinção, para fins didáticos, não significa que na prática não tenha havido mútuas concessōes, interferências, complementaçōes e até mesmo ambigüidades. Um exemplo claro é a Declaração dos Direitos do Homem e do Cidadão na Revoluçâo Francesa: "os homens nascem e permanecem livres e iguais no que toca os seus direitos", poderia ser considerada tipicamente um direito natural do jusnaturalismo, pois, embora fruto da Revolução Francesa, a Declaração fora precedida pelo Bill of Rights inglês e a Revolução Americana.

Estas duas posturas ideológicas tinham em comum o contratualismo e o convencionalismo para a organização político-social. Diferiam quanto à concepção de homem: para os jusnaturalistas havia direitos inerentes à natureza do homem, individuais; para os convencionalistas os direitos seriam atribuidos após uma reflexão e concordância da sociedade. Para esta segunda postura, os direitos teriam sua origem não no individual, mas no social. Deveriam, portanto, ser coletivos e concedidos pelo poder público.

Ora, esta questão ainda é atual. Assistimos não só no Brasil, mas no mínimo no Ocidente, o debate sobre os Direitos Humanos, os direitos sociais, direitos políticos entre outros. Pretendemos, por isso, trazer a público o debate originário, na sua fonte primeira, que se deu na Grécia Antiga, sobre os direitos, quer naturais quer convencionais.

Nossa hipotese é de que os gregos antigos tenham levantado a problemática das leis: serem obras de um grupo em proveito de quem as elaborou e, portanto, relativas e transitórias ou uma decorrência de valores consensuais e, por isso, gerais e duradouras.

\section{1 - OS PRÉ-SOCRÁTICOS}

$\mathrm{Na}$ antigüidade grega, os protótipos do convencionalismo foram os sofistas, no século V A.C. Naturais da Grécia e da Grande Grécia, perambulavam pelas cidades gregas atuando como professores populares. Embora defendessem as mais diversas doutrinas, possuíam entre si traços característicos, dentre os quais podemos destacar a contestação da opinião dominante, o descompromisso com a coerência, o ataque às autoridades e o solapamento da moral e da fé.

Destacaram-se neste magistério popular Protágoras, Hipias, Galice, Trasímaco, Pródigo e outros. Erigindo o "homem como medida de todas as coisas", Protágoras instituiu o individualismo, subjetivismo e relativismo, pois liquida com a possibilidade de princípios gerais. Negando estes, não é possível a ciência, e até mesmo, a possibilidade de se estabelecer parâmetros ou princípios para a justiça. O direito não passa da lei do mais forte. Conforme Trasímaco, a Justiça é um bem do outro.

No que tange à idéia de lei, os sofistas sustentaram três teses fundamentais:

19) As leis são criações artificiais, sendo válido somente - que se baseia na lei natural;

$\left.2^{\circ}\right)$ Além da Pólis há a Humanidade;

$3^{\circ}$ ) O Estado é convencional, e por isso, não decorrente de uma lei natural.

Os sofistas identificavam: a legalidade e a justiça com a força, conforme Trasímaco; a legalidade com a fraqueza, conforme Cálicles; lei e tirania, conforme Hípias ${ }^{2}$.

Em questões morais, os sofistas eram céticos. Esta postura favorecia seus fins lucrativos. Com isto podiam provar tudo o que seus clientes Ihes solicitassem ${ }^{3}$.

Bem de acordo com a vertente convencionalista, desenvolvem uma pedagogia contestatória, e em segundo plano uma crítica. Mais negavam e destruíam do que afirmavam ou construíam. Utilizavam-se da racionalidade para negá-la. Reduziram todas as regras a convenções. Tudo era permitido, desde que útił. Çada um é livre para seguir a natureza e seus instintos ${ }^{4}$.

As conseqüências de suas posturas foram indiretas, pois motivaram toda uma reação contra estes iconoclastas. Despertou o verdadeiro método crítico, procurando joeirar o bem do mal.

Outra escola que indiretamente desembocará 
na mesma visão será a Escola Epicurea, fundada por Epicuro no século IV A.C. Contrariamente ao que estava em voga, este pensador sustentava que a virtude não era um fim, mas um meio para se atingir a felicidade. Desse modo, a própria virtude adquire um caráter utilitário. A temperança tinha por objetivo, ou eram um meio, para se assegurar o maior prazer possível. Não se podia buscar qualquer prazer, nem fugir de toda dor, mas calcular para que o produto final ocasione o maior prazer possível com o mínimo de sofrimento.

Pedagogicamente a Escola Epicurea - a escola do Jardim - possuía propostas diversificadas, depedendo do grau cultural de quem a procurasse. Aberta à plebe, conforme Sêneca, ou aos incultos, conforme Lactâncio, mantinha para o público em geral o Tetrapharmacon (Remédio Quádruplo), conforme é explicado na Carta a Meneceu. Para se chegar à felicidade é necessário aceitar certas crenças e meditá-las. A primeira é a bemaventurança e imortalidade de Deus. Segunda, vencer o medo da morte. A partir de então, deve-se procurar a qualidade de vida. Para tanto, saúde e tranqüilidade, sendo esta última mais importante. O homem possui desejos naturais e outros não. Dos naturais, alguns são necessários, outros não. Dos necessários, alguns dão felicidade, outros conforto físico. A felicidade depende da boa escolha.

No que diz respeito à política, não é outro o critério adotado por Epicuro, isto é, o utilitarismo. A sociabilidade do homem não é natural, ao contrário provém do conflito. A luta causava sofrimento, desprazer $e$, portanto, o homem a evitou instituindo a sociedade $e$ o Estado. Por isso, o Estado, e com ele a lei, provém de um apetite natural utilitarista que quer afastar 0 desprazer. Por outro lado, se o homem perceber que o Estado novamente pode lhe causar sofrimento, opta pelo mais últil, suprimindo-o. Conseqüentemente a vida em sociedade, juntamente com suas leis ou costumes, não passam de um contrato social, revogável sempre que o prazer causado for menor que o sofrimento . Percebese, por isso, tanto nos sofistas como nos epicuristas o caráter convencionalista das leis, bem como a idéia de uma moral relativista, dependente das circunstâncias .

\section{SÓCRATES}

Contemporâneo do sofistas e epicuristas outro pensamento vinga na Grécia Antiga, talvez até como uma reação ao caráter demolidor da sofística. À vertente convencionalista de conceito de lei, contrapôs-se a vertente da lei natural. Esta, como dissemos, não pretende estabelecer um divisor intransponivel entre 0 natural, dado pela natureza, e a criação do homem. Isto justamente porque concebiam o homem como parte integrante da natureza, e sua atividade, embora racional e superior, estava adstrita ao seu contexto, isto é, ao natural.

Contra o pensamento dos sofistas se insurge
Sócrates (399-269 a.C.), precisamente na questão das generalizações. Para ele os conceitos tinham valor universal e, portanto, era possivel o conhecimento, bem como, em moral, propor-se leis gerais de conduta. Ao relativismo científico-moral, opõe-lhe a certeza. Isto foi possível graças ao avanço introduzido na questão dos conceitos: são gerais, abstratos e necessários, enquanto as coisas são particulares, sensiveis e contingentes. O homem, através de sua razão, capta o dado natural e o formula em conceitos. Há uma correspondência adequada entre aquilo que o homem elaborou com sua capacidade mental e aquilo que a natureza apresenta fenomenologicamente. $O$ dado particular e o conceito geral estão em sintonia. Não é uma ruptura, mas uma continuidade. Levada à política e às leis, esta postura gnoseológica implicará em respostas diversas as dadas pelos sofistas e epicureus.

Sócrates não se referiu a uma lei natural propriemente dita ou a um direito natural. No entanto, ao proceder a crítica aos sofistas contrapõe-lhe a racionalidade das leis e da moral, apontanto para a questão da racionalidade e generalidade em oposição aos instintos, aos sentimentos e à relatividade. Para ele, a virtude é inteligência, razão e ciência. Discorda, portanto, também dos epicureus, para os quais a virtude é um meio para o prazer. Em Sócrates, virtude é conhecimento e vício é ignorância. $O$ fim do homem é o bem e não o útil. Ao declarar que era preciso alçar-se aos sentidos, propunha o ordenamento da ordem natural através da razão. Era preciso procurar os princípios na natureza e não segui-la cegamente. Por isso era preciso buscar a universalidade.

A Justiça não consiste apenas em normas e leis, mas numa Justiça Superior, oriunda da divindade, do daimon, ou da racionalidade. Nesse sentido há um "cum sensu" entre a ordem cósmica até mesmo teológica - e a atividade racional do homem? ${ }^{7}$. A lei positiva não é mera criação do homem, mas descoberta daquilo que a natureza encerra em si. Por isso, até mesmo as leis positivas são invioláveis e soberanas . Em resumo, Sócrates apresenta uma Lei, acima da lei humana, a governar o universo e os homens. Não há oposição entre àquela Lei e a dos homens. Seguir a Lei Superior, dispersa na natureza, e descoberta pelo homem traduzindo-a em lei positiva, seria concretizar a Justiça, ou a bondade.

Após Sócrates advirão os dois maiores expoentes na Antigüidade, do convencionalismo utopista e do consensualismo: Platão e Aristóteles.

\section{PLATÃo}

A questão da universalidade dos conceitos foi solucionada por Platão, dando-lhe existência real, embora imaterial. Concebeu um mundo de Essências, as quais projetavam suas sombras sobre este mundo. A razão humana, que conhecera aquele mundo, 
reconhece as sombras daquelas essências, as idéias, e como tal pode conhecer as leis morais e fazer ciência.

Sua concepção de lei está intimamente ligada à Lei Perfeita do Mundo das Idéias.

O tema central que anima a meditação de Platão é a idéia de Justiça, transferida, por ele, para o plano do Mundo das Idéias. A Justiça do Mundo das idéias identifica-se com o Bem Absoluto. E a Felicidade, por sua vez, se identifica com o Bem ${ }^{\text {. }}$

Na visão de Platão há uma permuta entre as essências e as sombras. Primeiramente, o homem deve dirigir-se ao mundo das idéias, aprender de lá o ideal e - transportá-lo para este mundo.

A respeito da origem da sociedade, Platão atribui-lhe às necessidades mútuas dos homens ${ }^{10}$. Estas dão origem à divisão do trabalho, e conseqüentemente, a uma divisão da sociedade em classes, presentes no Estado. Este é constituído de uma multidão de individuos, grupos dessemelhante e desiguais, intraclasses, inter-classes e extraclasses. Até mesmo a escravidão encontra justificativa na concepção de Platão, pois, conforme ele, trabalhos servis são incompativeis para homens livres.

Se nas questōes morais Platão extrai das Essências seus conteúdos, a organização sócio-politica é elevado por ele ao plano "ideal". Agora inverte a dialética. Na moral, o ideal pode se tornar natural, nas questões sócio-políticas o natural pode tornar-se ideal. Para ele é possivel constituir-se um Estado Ideal, com três grandes classes: filósofos, guerreiros e produtores, cada uma delas com funções específicas. Aos primeiros a direção política, aos segundos a defesa do Estado, e aos terceiros a sua manutenção ${ }^{11}$. Quais as leis morais que regem este Estado? Evidentemente, agora, Platão nāo vai mais buscar na práxis, pois, provavelmente a experiência narrada na Sétima Carta, não foi das mais felizes $^{12}$. O natural, serăo as leis morais do mundo perfeito das Idéias.

Para ele, o Estado ou a Pólis, deve ser justa, isto $\dot{e}$, deve reinar uma ordem e harmonia entre as classes. Para tanto, conforme ele, faz-se necessário estabelecer os limites entre o indivíduo e o social.

A justiça é uma virtude individual, mas seu parâmetro é social. $O$ indivíduo será tanto mais justo quanto mais for pela sociedade. Para que emerja o social, é preciso que o indivíduo desapareça. Para tanto deve-se seguir os princípios do bem da coletividade: vontade comum, concretização das finalidades funcionais das classes e o Bem Supremo, isto é, Deus como "medida de todas as coisas".

A harmonia e a ordem devem assentar-se sobre quatro virtudes cardeais: a sabedoria, para os governantes-filósofos; a coragem, para os guerreiros; a temperância, tanto para os artísticos como para os guerreiros; e a justiça, significando a identificação com a ordem universal.

$\mathrm{Na}$ Pólis ideal, a individualidade desaparece, a começar pelo sexo, pois homens e mulheres não deverão ter nem educação, nem funções diferentes. Platão justifica sua posição, sustentando que a Natureza não faz diferença entre o homem e a mulher. Ambos possuem as mesmas aptidões físicas e domínios técnicos. Em seguida defende a supressão da família, devendo as mulheres serem comuns para guerreiros $e$ guardiōes. O Estado regulamentará a procriação, bem como se encarregará da educação das crianças, as quais ignorarão seus pais.

No que toca aos bens, deverão ser comuns, permitindo-se uma propriedade restrita aos artífices, desde que supervisionada pelos guardiōes.

Finalmente, a Polis será governada por sábios, por reis-filósofos.

Os governantes seriam escolhidos entre as crianças que demonstrassem aptidões naturais, independente da origem social. Deveriam ter aptidão física, gosto pelo estudo, inteligência e memória, constância e esforço. Moralmente, irascibilidade, sabedoria, temperança e grandeza de alma. Os que preenchessem estes quesitos, receberiam do Estado uma Educação que duraria até os cinqüenta anos, quando então estariam aptos para o governo da cidade, protótipa do Cosmos Universal.

Em que pese de que na sua última obra, As Leis, Platão tenha revisto muitos dos seus pontos de vista, como a família, propriedade, educação e igualdade dos sexos, o caráter utópico totalitário de suas propostas políticas não desaparecerem, nem mesmo prọpondo o Conselho Noturno e a Assembléia do Povo.

Na verdade, Platão preconiza uma sociedade perfeita, regida por homens incorruptiveis e integrada por membros naturalmente bons. E é nisso que consiste seu caráter utópico. Há uma identificação do natural com o perfeito, ou divino. No entanto, concretamente não se constata esta realidade, como o próprio Platão narrou na Sétima Carta. A sociedade é minada de conflitos, os homens que governam são corruptos, e os membros integrantes da sociedade são bons, mas também há os maus ${ }^{14}$. Fechar os olhos para os conflitos, quer na sociedade, quer já prática política, significa fazer de conta, convencionar, que eles não existem. A partir disso, transplanta um modelo ideal, utópico para uma sociedade real. A priori, convenciona que, desde que o governante seja bem esclarecido, ele se pautará por leis justas, e os membros da sociedade individualmente e em grupos, as seguirão fielmente. Ficam, por isso patentes as características artificiais, convencionais e utópicos das leis propostas por Platão.

Há ainda que se destacar o caráter totalitário das propostas políticas deste pensador. O Estado préestebelece todos os comportamentos lícitos da sociedade. O princípio é de que só é permito o que a lei estabelecer. Fecha, por isso, todos os espaços para a iniciativa individual ou grupal. O Estado sabe o que cada um necessita para ser feliz. Qualquer discordância 
seria considerada ignorância, ou má intenção. Embora o recrutamento dos guardiões não se atenha a uma determinada classe, a educação que irão receber lavagem cerebral - farão deles uma casta de burocracia imunes a qualquer tipo de discordância ou oposição.

\section{ARISTÓTELES}

O maior representante da vertente da lei natural na Antigûidade é Aristóteles. Nele, a idéia de um direito natural, isto é, um direito inerente à natureza humana e, portanto, independente de uma lei positiva reguladora, encontrou a mais coerente formulação. O problema levantado pelos sofistas de que as leis não passam de convenções, e por isso são artificiais, havia merecido de Sócrates contra-proposta da racionalidade. No entanto, seus argumentos assentavam sobre a autoridade da divindade. Platão, se abandona o argumento teológico, responsável por um mundo ideal, utópico, que no fundo não deixava de ser também convencional.

A originalidade de Aristóteles é de ter respondido à questão sem fugir para uma ordem extra-natural. Conforme ele, a realidade circundante, na natureza, expressava a tendência de todo natural em busca do ato. $O$ desenvolvimento da potência encaminhava os seres para a sua forma e finalidade. Os seres em si continham em germe a sua própria perfeição. Os instintos primários são potência para algo superior, qual seja, o homem político. O homem, por isso, ao desenvolver sua natureza está a caminho da Pólis ${ }^{15}$.

Não é, porém, qualquer desenvolvimento que leva o homem a ingressar na sociedade superior, mas o desenvolvimento moral. O impuiso intrínsico da natureza humana para a perfeição. $O$ aprimoramento moral leva o homem à convivência política. Por isso, quando as leis coincidirem com o progresso moral, não há oposição entre a lei natural e a lei positiva. O elo de ligação entre a lei natural e a lei positiva se faz pela moral. E como esta está em potência em cada homem, seu desenvolvimento dá origem ao consenso. Quando as lei positivas forem decorrentes do desenvolvimento moral, obtém-se uma ordem consensual.

Para Aristóteles, a sociedade política significa um estágio superior do homem. No entanto, numa sociedade política, nem todos são cidadãos. Estes são membros plenos, enquanto os demais hierarquizam se em ordem decrescente até o escravo. $O$ cidadão era aquele que havia desenvolvido suas potencialidades naturais e chegara a ser membro do Estado. Este não é mero fruto da necessidade, como queriam os sofistas, mas uma união perfeita e orgânica de seus membros para a virtude e felicidade. O Estado, por sua vez, proporciona a seus membros todo bem-estar. Indivíduo e Estado completam-se numa simbiose perfeita, cabendo a este regular a vida dos cidadãos ${ }^{16}$.

Nem em Platão e nem em Aristóteles encontramos uma preocupação maior de estabelecer limites ao Estado. O pensamento destes filósofos partiam do pressuposto de que o Estado sempre faria leis moralmente justas. Consideravam-no como uma Igreja que dá orientação moral e estímulo para seus membros. Daí se entende os diversos tipos de leis, as quais objetivavam sempre a justiça, a qual também se diversificaria. Haveria a distributiva, que atendia às desigualdades individuais. Para se atingir a igualdade, era necessário levar em conta a desigualdade, conforme Aristóteles. A justiça corretiva, que procurava estabelecer uma relação justa entre o delito e a pena. Em Aristóteles encontramos a noção de bilateralidade da justiça, isto é, uma proporção inter-cidadãos e não apenas intra-cidadão como ocorria com Sócrates e Platão. Conforme ele, não há justiça de um homem consigo messmo. A justiça está inserida na sociabilidade $^{17}$.

Como vimos, a perfeição das potencialidades inerentes em cada homem se concretiza no ato político. É o homem na sua plenitude moral. Daí que os fins e o bem do homem não são atingidos pela retórica, econômica, ou mesmo a ética. É necessário avançar até a Política, culminância do homem, somente atingida pelo cidadão ${ }^{18}$.

Segundo o Estagirita, a virtude pode ser dividida em duas espécies: a dianoética, que sqgadquire pelo conhecimento, e a ética, pelo hábito. Nenhuma dessas virtudes se geram pela natureza (não é a função que faz o órgão, mas ela o supõe). O mesmo se dá com a virtude, pois o ato precede a virtude. A virtude não está em potência no homem, ela é a perfeição do ato humano. $O$ segredo para se atingir a virtude é a prática de atos bons, sem excessos, observando a justa medida ${ }^{20}$. Por isso, a virtude é o hábito de atos bons. $A$ virtude, e somente ela, conforme Aristóteles, traz felicidade ao homem. Produz atos que são fins em si mesmos.

A sociedade política é essencialmente moral para Aristóteles. As leis originárias desta sociedade são o reflexo de uma comunidade de homens virtuosos que se pautam pela racionalidade. A convivência social é o resultado da congregação de famílias que abarcam, pela própria natureza, o homem, a mulher, os filhos e os criados. As várias familias congregadas dão origem à aldeia, ou à vila. E da união de vilas surge o Estado, que é a globalidade ${ }^{21}$. E dentro do Estado, o membro superior, o "full member" como diria Locke, é o cidadão. Este "tem uma parte legal na autoridade deliberativa e na autoridade judiciária ${ }^{22}$. O bom cidadão acompanha a organização política de sua cidade e sabe bem o que the compete.

Considerando o Estado a globalidade, no momento que se impuser, desaparece a parte, ficando apenas o nome. Visto concretamente, não na seqüência cronológica, mas como um fato político, o Estado precede o individuo e a família ${ }^{23}$. 
Conforme Aristóteles o Estado é soberano interna e externamente. A soberania externa é garantida pela autosuficiência econômica, ou a não dependência. Desde que um país dependa economicamente de países externos, estará comprometendo sua soberania. O ideal, conforme ele, seria cada cidade tornar-se uma potência agrária, como seria o caso da Lacedômia.

Internamente, a quem cabe a soberania? $\mathrm{Na}$ maioria constituída de pobres? Evidentemente que não, pois estaria praticando injustiça. Numa pessoa, geralmente um tirano? Também não, pois nem sempre agiria conforme a justiça. A minoria, constituída de ricos? - Igualmente não, pois poderia praticar os mesmos atos da maioria. Conforme ele, a soberania cabe à multidão, comandada por homens eminentes. A multidão faz um homem só, com uma infinidade de pés, mãos, sentidos, costumes e inteligência. Há uma apreciação do conjunto, e disso sai o melhor julgamento, que é do povo ${ }^{24}$. Mas não só porque a multidão é numericamente a maioria detém a soberania, mas também porque seria proprietária da maioria dos bens materiais ${ }^{25}$.

Quanto à forma de governo, Aristóteles constata três formas puras, as quais, degenerando, dão origem à três impuras. A realeza, opõe-se à tirania; a aristocracia, opõe-se à oligarquia; e a república, à democracia. Das corruptas a pior é a tirania, seguida pela oligarquia. A mais tolerável é a democracia ${ }^{26}$. Mas por que ocorrem as corrupções? Conforme Aristóteles, é porque se desobedece a lei da natureza. Esta institui na sociedade naturalmente a diversidade. Existem funçōes diversificadas, classes mais abastadas e menos abastadas, talentos maiores e menores. Sendo a sociedade naturalmente diferenciada, a quebra dessa ordem provoca desvios, como é o caso das formas de governo. Além disso, não basta atender-se tão somente aspectos materiais da vida em sociedade, mas também aspectos morais: "como se uma cidade só existisse para a satisfação das necessidades materiais e não para um objetivo moral - como se a virtude não lhe tosse mais necessária que sapateiros e lavradores "27. A ruptura da ordem natural em Aristóteles significa também uma violação de leis morais. $O$ homem desrespeita a natureza, afasta-se da moral e implanta a artificialidade. Faz de conta que só existe o interesse de uma pessoa, a conseqüência será a tirania. Se pensar que existe o interesse de uma minoria somente, cairá na oligarquia. Se pensar que todos são iguais, produzirá a democracia.

Aristóteles enumera cinco espécies de democracias, conforme os critérios de organização político-social. A primeira delas é a que se fundamenta na igualdade. Faz " tábula rasa "entre ricos e pobres. Como, geralmente, os pobres são mais numerosos, esta democracia terá como opinião predominante a dos pobres. Quando se convencionar o censo como critério de participação política, teríamos, evidentemente, uma democracia censitária. Uma terceira espécie institui a moralidade como critério. Estando assentada na leí, não haveria injustiças. A quarta, estabeleceria que o simples fato de ser ${ }_{28}$ idadão poderia tomar parte nas

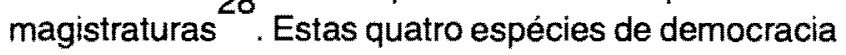
não dispensam a lei, ao contrário a supõem. Há, porém, um quinto tipo de democracia: a popular, que transfere a soberania da lei para a turba eventual.

Esta democracia, pelos seus princípios e processos, poderia ser denominada de democratismo. Com efeito, ainda conforme Aristóteles, a lei perde a soberania sendo a comunidade governada por decretos. Não sendo mais a lei a soberana, pululam os demagogos ou populistas. O povo se transforma num monarca, com poderes absolutos sobre tudo, todos em qualquer momento. Guia-se ao sabor das conveniências do momento. Uma esfera da lei, proveniente de um consenso moral, desaparece, para dar lugar ao momento. Crê-se que tudo não passa de convenção podendo-se modificar sempre que se achar conveniente. Os demagogos ou populistas adotam o processo de continuamente consultar o povo. Uma vez obtido o resultado, transforma-o em decreto que vigorará até próxima decisão popular. Seu poder não conhece limites, pois eles mesmos já sabem diante mão o que é mais agradável à turba. Se alguém se atraver a thes fazer oposição, não hesitam em consultar a multidão e jogar no ridículo qualquer autoridade. Arremata Aristóteles:

Os demagogos são a causa de a autoridade soberana repousar nos decretos, e não as leis, pelo cuidado que thes tomam de tudo conduzir ao povo; disso resulta que eles se tornam fortes, porque o povo é senhor de tudo, e eles próprio são senhores da opinião da turba, que só a eles obedece. Além disso, aqueles que tenham censura a fazer aos magistrados, pretendem que ao povo compete decidir. Este consente de boa vontade em ser convocada a sua autoridade $e$ disso resulta a dissolução completa de todas as magistraturas $^{29}$.

Por isso, conforme Aristóteles, o abandono da lei natural, isto é, despojando a lei de seu caráter moral, intimamente ligado à própria natureza do homem, põe por terra todo o respeito à lei, condição sine qua non de uma ordem político-social. As conseqüências desta conduta leva a toda sorte de degenerações políticas, dentre as quais pode-se apontar o populismo. Aristóteles conseguiu captar os princípios e métodos dos governos populistas que podem ser denominados de democratismo.

\section{5 - OS ESTóicos}

Ainda entre os antigos gregos, e posteriomente com os romanos, encontramos bem fundamentada uma idéia de lei natural entre os estóicos. Esta escola tem 
como precedentes a escola dos cínicos, representados principalmente por Antístenes e Diógenes. Com Sócrates, Aristóteles e Platão compartilhavam com a idéia de virtude. As únicas leis admissiveis seriam as leis da virtude. $\mathbf{E}$ como estas leis são universais, o homem deveria sentir-se cidadão do universo, um cosmopolita. Desprezavam as leis positivas, e com isso aproximavam-se dos sofistas.

Os mais renomados estóicos foram Zenão de Cipro, Cleante e Crisipo. Entre os romanos destacaramse Sêneca, Marco Aurélio, Possidônio e outros. A sabedoria, conforme eles, reside na liberdade. Para se chegar a ela, o homem necessitava livrar-se das paixōes e das influências exteriores. Este ideal era uma exigência da reta razão. O homem é partícipe da lei natural e da lei interior (consciência). Estas o levam para o ideal da liberdade. Por isso, para se chegar a ele, deveria viver conforme o lema: "segue a natureza".

Os estóicos consideravam-se cidadãos do mundo e pretendiam erigir um Estado Universal. A sociedade abrange todo o gênero humano. O próprio universo mitológico é incluído nessa visão cosmopolita. Marco Aurélio dizia que todos os homens são cidadāos da República de Zeus ${ }^{30}$.

Embora o universo esteja continuamente em movimento, as sociedades em permanentes mudanças e os homens constantemente se deslocando de um lugar para outro, sempre permanece a natureza comum dos homens. Dizia Sêneca:

Mas nos seguem em toda parte as duas coisas mais belas: a a natureza comum a todos e a virtude individual $^{31}$.

É significativo, não só para a filosofia política, como para todo um ideal grego, acalentado por Platãoe Aristóteles, a concretização da idéia de um rei-filósofo, na pessoa de Marco Aurélio.

Em seu livro "Meditações", propõe uma filosofia político-social calcada sobre a virtude e a filosofia estóica. No livro I, após enumerar as virtudes que aprendeu de seus parentes mais próximos, descreve como leva sua vida de Imperador e partidário do estoicismo. Diz ele, que vive na corte sem guarda pessoal, dispensando roupagens aparatosas, ou ornamentação exagerada. Praticamente levava uma vida igual aos demais. Mas nem por isso deixava de cumprir suas obrigações de chefe de estado. A vida que levava, segundo ele, era de conformidade com a natureza. Apesar de não possuir boa saúde física, conseguia suportar as exigências de suas funçōes. Havia afastado as paixões amorosas. O relacionamento com o pessoal da corte era correto, pois de nada podia ter remorços. Nunca pedia emprestado. Com sua esposa, Faustina, levava uma vida normal, pois, conforme ele, ela the obedecia, era afetuosa e simples. É grato aos deuses porque, quando conheceu a filosofia, não foi através dos sofistas ${ }^{32}$

Após enumerar as virtudes, os cuidados, a verdadeira sabedoria do homem, aponta para a idéia de Humanidade, baseada na natureza ${ }^{33}$. Cada homem, e todos os seres, são efêmeros e partes do todo ${ }^{34}$.

A idéia de um Império Universal, calcado na idéla de natureza comum, ia ao encontro do "status quo" do Império Romano; por isso, identificava-se sua filosofia política pessoal com a oficial de Roma.

Conforme ele, o homem virtuoso está acima das leis. Aliás, não encontramos preocupações maiores com elas nas Meditaçōes. Uma das virtudes que destaca é a tolerância. No entanto, parece que os cristãos fizeramno perder a paciência...

Vê-se, portanto, que a idéia de uma lei da natureza embazava a filosofia política do estoicismo. Nele, natureza e virtude constituem o binômio básico para se chegar à liberdade. Em que pese o fato de não se prestar muita atenção às leis positivas, pouco se importando com as relações mútuas, natureza e positividade, subjaz a idéia de que a lei da natureza é sobremaneira, mais importante, inclusive, podendo-se dispensar as leis positivas, quando bem observadas as leis da natureza. Diante disso, poderíamos alinhar o pensamento político estoico, dentro da mesma linha de Aristóteles, qual seja, na vertente consensual, já que a lei comum da Humanidade dá sustentação às demais leis.

\section{CONCLUSÃO}

Basicamente quatro grandes grupos, na Grécia Antiga, concorreram para o debate em torno da idéia de lei: os sofistas, os platônico-aristotélicos (os socráticos estão incluídos), os epicureus (Escola do Jardim) e os estóicos. O divisor maior se estabelece entre os sofistas e os platônico-aristotélicos. Os estóicos se aproximam destes e os epicureus daqueles.

O início do confronto ideológico deu-se por iniciativa dos sofistas que, no intuito de defender os interesses de seus constituintes passaram a contestar - "status quo" institucional. A estratégia foi relativizar idéias e instituições para justificar as pretensões de seus clientes. Ao defenderem que a Justiça é a lei do mais forte, anulavam a idéia de uma Justiça geral, imparcial e duradoura. A lei não passava de uma convenção, como diziam.

A resposta veio primeiramente por Sócrates e depois por Platão e Aristóteles. Estes posicionaram pela imanência, cada um a seu modo, de uma lei na natureza humana, e ao segui-la se faria a Justiça. Além disso, patentearam as contradições dos sofistas, os quais queriam que suas idéias fossem verdadeiras, mas defendiam a relatividade de tudo. Platão e Aristóteles diferem no que concerne à fonte primeira da lei. Para o primeiro é o sobrenatural o mundo perfeito das idéias; para o segundo é o mundo natural. Em ambos, porém, 
há uma lei natural. Em ambos, porém, há uma lei da natureza.

Os estóicos, pautados pelo "sequere naturam" incluíam no conceito de natureza, a razão. Defendiam o cosmopolitismo, isto é, uma cidadania universal. Para eles, o homem acima de tudo deve ser virtuoso e, para tanto, basta seguir a lei natural, a qual Ihe dará também a felicidade.

O epicurismo, a escola do maior prazer possível com o mínimo de sofrimento, envereda para o materialismo, o qual causa o relativismo ético-moral. Nada haveria de permanente, imutável. Embora Epicuro não fosse partidário de uma anarquia institucional, ao contrário defendia sempre a moderação, suas idéias desembocaram no descompromisso do indivíduo para com seus semelhantes, podendo, cada um agir como Ihe aprouvesse.

Os princípios dos epicureus levavam ao convencionalismo e dos estóicos à lei natural.

Por isso, com os antigos gregos teve início o debate que daria origem ao contratualismo da Idade Moderna, que, por sua vez, se desdobrou em jusnaturalismo e convencionalismo, no que se refere ao conceito de lei.

MALFATTI, S.A. Natural law $x$ ancient convention. Semina: Ci. Sociais/Humanas, Londrina, v. 17, n. 3 , p. 321-329, Sep. 1996.

ABSTRACT: This paper discusses the debate ocurred among the ancient Greeks about the nature of the law. Basically two trends were confronted: the defenders of a "natural law" and conventionalists. Among the first we may mention Socrates, Plato, Aristoteles and the Stoics. In the latter there were the sophists and epicureans. The ones that are favorable to the natural law argued that man was born with the law and when he complies with it, justice is done. Around this idea it may be obtained a society consensus about what to do and what not to do. The consensus would be in fundamental matters and with this the law could be stable, general, above group interests and mainly fair. The convencionalists, on the contrary, thought that the mencioned consensus was only a disguise of the hegemonic group. And if the law were a mere fancy of the dominant group, it would be transitory, particular, casuistic and mainly an impositive force. This debate was so significative that it was not lost in History, it was maintained in the Middle Age and it was lighted again in the Modern Age with the contractualism divided between naturalists in favor of a natural law and conventionalists in favor of an absolute relativy of the laws. Even in the Contemporaneous Age the two trends were confronted and still do, evidenttly coated with other clothes. The great majority of the liberals, for example, are submissive to the naturalism and the great majority of the marxists follow the convenciolist trend. For sure, nowadays the defenders of the "alternative right" have their roots in the conventionalism, and the followers of the idea of an impersonal right own their inspiration to the natural right.

KEY-WORDS: Natural law, convention, consensus and relativism.

\section{REFERÊNCIAS BIBLIOGRÁFICAS}

1. FURRET, François e RICHET, Denis. La Revoluzione Francese Vol. I, Roma-Bari, Editora Laterza, 1988, p.65.

2. PLATÃo. A República. $5^{a}$ Ed., São Paulo, Atena, s.d., p.70 a 90.

3. PLATÃO. Górgias ou a Oratória. Trad. de Jaime Bruna. São Paulo, Difusão Européia do Livro, s.d., p.70 a 90.

4. Id. p. 130.

5. FARRINGTON, Benjamin. A Doutrina de Epicuro. Trad. de Edmond Jorge. Rio de Janeiro, Zahar Editores, 1968, p. 132 ss.

6. FARRINGTON, Benjamin. A Doutrina de Epicuro. Trad de Edmond Jorge. Rio de Janeiro, Zahar Editores, 1968, p. 132 SS.

7. PLATĀo. Diálogos. Vol. II, Fédon, Sotista, Político. Trad de Jorge Paleikat e Cruz Costa. Porto Alegre, Globo, 1955, p. 270 a 296

8. ARISTÓTELES. Política. L. III, 21, 3.

9. Górgias, op. cit. p. 92.

10. A República, op. cit. p. 72 a 83 , L. II.

11. A República, op. cit. p. 72 a 83, L. II.

12. PLATĀO. Sétima Carta. Revista: Humanidades. Brasilia, UnB, Vol. $1, n^{\circ} 2$, Jan/Mar/1983, p. 171 a 184.

13. MAIRE, Gaston. Platão. Trad. de Rui Pacheco, Lisboa, Edições $70,1966, p .50$ a 63

14. Sétima Carta, op. cit. p. 184.
15. ARISTÓTELES. Ética. Trad. de Cassio M. Fonseca. Rio de Janeiro, Edições de Ouro, 1968, L. I, 5.

16. A Ética, op. cit. LV, c. I.

17. ARISTÓTELES. A Política. Trad. de Nestor Silveira Chaves. $5^{\text {a }}$. ed., São Paulo, Atenas Editora, s.d., L. I, cap. I, 12.

18. A Ética, op. cit. L II, IV, 2.

19. A Ética, op. cit. L. II, IV, 2.

20. Id. L. II, I, 4.

21. A Politica, op. cit. L. I, cap. 1,4 a 14

22. Id. L. II, cap. I, 8 .

23. Id. L. I. cap. I, 11.

24. Id. L. II, cap. VI, 4.

25. Ibd, 12.

26. Id. L. VI, cap. II, $2^{\circ}$

27. Id. L. VI, cap. III, 12.

28. Id. L. VI, cap. IV, 2 e 3 .

29. Id. 6.

30. MARCO AURÉLIO. Meditações. L. IV, 23 e BRUN, Jean. $\underline{O}$ Estoicismo. Trad. de João Amado. Lisboa, Edições 70 , s.d., p. 88.

31. SÉNECA, Lúcio Aneu. Consolação à Minha Mãe Hèlvià. Trad. de Giulio Davide Leoni. Os pensadores. São Paulo, Abril Cultural, VIII, 2.

32. Meditações, L. I, 17

33. Id. L. III, 4.

34. Id. L. VIII, 34 


\section{BIBLIOGRAFIA}

1. ARISTÓteles. A Ética. Trad. de Cassio M. Fonseca. Rio de Janeiro, Edições de Ouro, 1968, L. I, 5.

2. ARISTÓTELES, A Política. Trad. de Nestor Silveira Chaves. $5^{\mathrm{a}}$ ed., São Paulo, Atena Editora, s.d.L. I, cap. I, 12.

3. EPICURO. Epistola a Meneceu. Apud: FARRINGTON Benjamin. A Doutrina de Epicuro. Trad. de Edmond Jorge. Rio de Janeiro, Zahar Editores, 1968, p. 129 a 132.

4. FARRINGTON, Benjamim. A Doutrina de Epicuro. Trad. de Edmond Jorge. Rio de Janeiro, Zahar Editores, 1968, p. 132 ss.

5. FURET, François e RICHET, Denis. La Revoluzione Francese. Vol. I, Roma-Bari, Editora Laterza, 19889, p. 65.

6. FARRINGTON, Benjamim. A Doutrina de Epicuro. Trad. de Edmond Jorge. Rio de Janeiro, Zahar Editores, 1968, p. 132 ss.

7. MAIRE, Gaston. Platão. Trad. de Rui Pacheco. Lisboa, Edições 70,1966, p. 50 a 63

8. MARCO AURÉLIO, Meditaçóes. L. IV, 23 e BRUN, Jean.
O Estoicismo. Trad. de João Amado. Lisboa, Edições 70 s.d., p. 88

9. PLATÃo, A República. $5^{\text {a }}$ ed., Sāo Paulo, Atena, s.d., p. 26 a 30.

10. PLATÃo. Diálogos. II Vol., Fédon, Sotista, Político. Trad. de Jorge Paleikat e Cruz Costa. Porto Alegre, Globo, 1955, p. 270 a 296

11. PLATÃO, Górgias ou a Oratória. Trad. de Jaime Bruna. São Paulo, Difusão Européia do Livro, s.d., p. 70 a 90.

12. PLATÃo. Sétima Carta. Revista: Humanidades. Brasília, UnB, Vo. I, n² 2, Jan/Mar/1983, p. 171 a 184

13. SÉNECA, Lúcio Aneu. Consolacão à Minha Mãe Hélvia. Trad de Giulio Davide Leoni. Os pensadores. São Paulo, Abril Cultural, VIII, 2.

14. VECCHIO, Giorgio del. Liçōes de Filosofia do Direito. vol. I, Trad. de Antonio José Brandão. $4^{2}$ ed., Coimbra, Armênio Amado, 1972, p. 63 a 65. 